\title{
OPTIMALISASI PERAN PERBANKAN SYARIAH DALAM MENDUKUNG WISATA HALAL
}

\author{
Raden Bagus Faizal Irany Sidharta ${ }^{1}$ \\ ${ }^{I}$ Fakultas Ekonomi dan Bisnis, Universitas Mataram,
}

\begin{abstract}
ABSTRAK
Penelitian ini bertujuan untuk menganalisa peran bank syariah dalam mendukung wisata halal dan untuk menganalisa potensi bank syariah dalam mendukung wisata halal. Jenis penelitian ini merupakan penelitian deskriptif kualitatif berdasarkan hasil wawancara dan dokumentasi. Hasil penelitian menunjukkan bahwa bahwa kondisi bank syariah dalam mendukung wisata halal belum melakukan sosialisasi yang efektif kepada para pelaku industri wisata, akses kantor dan jaringan atm yang masih sulit ditemui serta kurangnya promosi yang dilakukan oleh perbankan syariah sementara potensi bank syariah itu sendiri dapat melakukan inovasi produk dengan memberikan kekhususan produk pembiayaan bagi para pelaku industri wisata serta melakukan event yang menarik agar dapat merubah mindset masyarakat bahwa bank syariah merupakan bank yang inklusif dan bukan eksklusif
\end{abstract}

Kata Kunci: Bank Syariah dan Wisata Halal

\begin{abstract}
This research aims to analyze the condition of sharia banking today in areas of supporting halal tourism and to analyze the potential of sharia banking in supporting halal tourism. This a research is the type of qualitative descriptive research, where there are more description of interview results and documentation studies. The obtained result is that the condition of sharia banking in supporting halal tourism is still insufficient due to the poor targeting of its socialization, the difficulty of access to branch office and ATM network and technology advancement that has not been provided also the lack of promotion by sharia banking while The potential of sharia banking in supporting halal tourism can do inovation with giving speciality funding for the people in tourism industry, and sharia banks can also hold event to support halal tourism so that it can change people mindset that sharia banking is inclusive banking and not exclusive banking.
\end{abstract}

Keywords: Sharia Banking and halal tourism

\section{PENDAHULUAN}

Indonesia sebagai negara dengan populasi penduduk beragama Islam terbesar di dunia hendaknya menjadikan industri halal sebagai lokomotif pembangunan ekonomi. Salah satu industri halal yang telah mengalami pertumbuhan dengan pesat adalah pariwisata halal atau wisata halal (Kemenpar, 2015). Hal ini dapat dibuktikan dengan meningkatnya peringkat Indonesia sebagai negara destinasi halaldunia dalam kurun waktu 3 tahun berturut-turut, pada tahun 2015 Indonesia berada pada peringkat 6 dengan skor 67.5. Pada tahun 2016 peringkat Indonesia naik 2 peringkat menjadi peringkat 4 menggeser Qatar dan Saudi Arabia. Tahun 2017 peringkat Indonesia naik menjadi peringkat 3 menggeser Turki dengan skor 72.6. Hal ini membuktikan bahwa pariwisata halal Indonesia merupakan sektor Industri halal yang sangat pesat perkembangannya. Didukung oleh penduduk populasi muslim terbesar di dunia, Indonesia seharusnya dapat menempati peringkat pertama sebagai negara tujuan traveler muslim dunia. 
Namun, Indonesia belum mampu sebagai peringkat pertama sebagai negara destinasi halal hal ini menunjukkan bahwa pariwisata halal di Indonesia belum digarap serius oleh berbagai pihak, padahal jika digarap lebih serius potensi pengembangan pariwisata halal di Indonesia sangat besar (Kemenpar, 2015). Menurut Rusmahafi (2015) terdapat empat komponen pendukung kesuksesan dari wisata halal ini di antaranya adalah penyedia jasa perjalanan, transportasi, menarik atau tidaknya wisata tersebut, hingga dukungan melalui penyedia layanan keuangan, yaitu bank syariah. Peran bank syariah sangat besar dibutuhkan dalam pengembangan wisata halal. Menurut (Violita \& Handarbeni, 2017) bank syariah hadir untuk dapat meningkatkan perekonomian nasional serta adanya kebutuhan akan praktik transaksi yang sesuai dengan prinsip Islam. Oleh karena itu, bank syariah dan wisata halal memiliki keterkaitan yang sangat erat dan tidak bisa dilepaskan satu sama lain. Namun, masih banyak permasalahan yang dihadapi oleh perbankan syariah itu sendiri. Pada tahun 2017, pangsa pasar perbankan syariah di Indonesia hanya sebesar 5,32 persen, tentu sebagai negara dengan mayoritas penduduk muslim terbesar di dunia, angka 5,32 persen tersebut masih sangat rendah dibandingkan dengan Malaysia yang telah memiliki pangsa pasar perbankan syariahnya mencapai 23,8 persen (Okezone, 2017).

Penelitian yang dilakukan oleh Junaidi (2015) menyatakan bahwa pemahaman masyarakat terhadap produk-produk perbankan syariah menjadi salah satu faktor yang paling menentukan bagi masyarakat dalam menggunakan produk-produk bank syariah, namun pada kenyataannya, pada tahun 2016 pemahaman masyarakat tentang produkproduk perbankan syariah masih sangat rendah. Hal ini tercermin dari Survei Nasional Literasi dan Inklusi Keuangan yang dilakukan oleh Otoritas Jasa Keuangan yang menemukan bahwa indeks literasi keuangan syariah sebesar 8,11 persen sementara indeks inklusi keuangan syariah sebesar 11,6 persen, hal ini mengindikasikan pemahaman masyarakat terhadap produk-produk keuangan syariah masih sangat rendah. Hal ini diperkuat dari hasil penelitian yang dilakukan oleh Rivai et al. (2015) yang menemukan bahwa perbankan syariah belum mampu untuk memberikan suatu persepsi yang baru terhadap produk-produk perbankan syariah itu sendiri.

Dengan kata lain, seharusnya perbankan syariah mampu untuk membangun image yang berbeda di mata konsumen dengan keunikan dari produk-produk perbankan syariah itu sendiri. Sementara itu, permasalahan lain yang dihadapi oleh perbankan syariah adalah adanya kesan eksklusifitas, bahwa perbankan syariah hanya dapat digunakan oleh orang-orang yang beragama Islam saja karena produk-produk perbankan syariah lebih di dominasi dengan menggunakan simbol-simbol Arab. Simbol eksklusifitas tersebut ditandai dengan banyaknya produk-produk perbankan syariah yang menggunakan istilah Arabtanpa memandang efisiensi dan efektivitas penggunaan istilah tersebut di kalangan masyarakat majemuk (Ghani, 2012). Tentunya, hal ini menjadi kontraproduktif terhadap wisata halal dimana wisata halal sendiri adalah wisata universal yang dapat dinikmati oleh seluruh kalangan tanpa memandang suku, agama, ras dan antar-golongan (Kemenpar, 2015). Untuk itu, penelitian ini bertujuan untuk menganalisis kondisi bank syariah saat ini dalam mendukung wisata halal dan untuk menganalisis potensi bank syariah dalam mendukung wisata halal.

\section{KAJIAN TEORI}

Istilah wisata halal dalam literature pada umumnya disamakan dengan beberapa istilah berikut ini seperti Islamic tourism, syari'ah tourism, halal travel, halal friendly tourism destination, muslim friendly tourism destination, dan halal lifestyle (Putra, 
2015). Wisata halal adalah kegiatan yang didukung oleh berbagai fasilitas serta layanan yang disediakan masyarakat, pengusaha, pemerintah, dan pemerintah daerah yang memenuhi ketentuan syariah (Kemenpar, 2015). Menurut Battour dan Ismail (2015) wisata halal adalah segala sesuatu yang diperbolehkan berdasarkan hukum Islam atau hukum syariah. Wisata halal, dimanfaatkan oleh banyak orang karena karakteristik, produk, dan jasanya yang bersifat universal. Halal diartikan dibenarkan, sedangkan haram diartikan dilarang. Wisata halal merupakan konsep baru pariwisata. Wisata halal bukanlah wisata religi seperti haji dan umroh. Wisata halal adalah melayani hiburan dengan menyesuaikan gaya liburan sesuai dengan kebutuhan dan permintaan traveler muslim (Kemenpar, 2015). Islam telah mengatur dan mengajarkan kepada seluruh umatnya untuk berlaku dan bertindak dalam kehidupan sehari-hari, seperti melaksanakan ibadah salat 5 kali sehari semalam dan menjauhi makanan dan minuman yang haram (Cetin dan Dencer,2016). Hal ini tentunya, tidak hanya sebatas pada makanan dan minuman, namun keterkaitan akan proses-proses bisnis dalam industri tersebut haruslah berlandaskan akan hukum Islam, dengan kata lain proses bisnis tersebut haruslah halal (Ismaeel dan Blaim,2012). Halal merupakan bagian dari sistem kepercayaan, kode etik-moral, dan integral dalam kehidupan sehari-hari. Sehingga, kata halal tidak hanya pada pemakaian yang dilakukan pada tataran konsumsi akhir saja, melainkan sumber atau produksinya pun harus berlandaskan kehalalan tersebut (Jaelani,2017). Sementara itu, menurut Shafaei dan Mohamed (2015) wisata halal merupakan suatu keterkaitan yang erat antara satu industri dengan industri yang lainnya, wisata halal merupakan perpaduan dari berbagai sektor industri salah satunya sektor keuangan halal atau keuangan syariah. Dalam keuangan syariah itu sendiri terdapat perbankan syariah dimana menurut UU No.21 Tahun 2008, perbankan syariah adalah kegiatan yang berhubungan dengan bank umum syariah dan unit usaha syariah yang mencakup kelembagaan, kegiatan usaha serta cara dan proses pelaksanaan kegiatannya. Lahirnya perbankan syariah dilandasi oleh keyakinan bahwa sistem bunga (riba) yang berlaku pada perbankan konvesional adalah sistem yang telah mengeksploitasi perekonomian dan cenderung tidak adil bagi salah satu pihak, tentu hal ini dilarang dalam prinsip-prinsip hukum Islam (Setiawan, 2006). Tentunya, dengan hadirnya perbankan syariah yang mengusung suatu sistem yang baru yaitu sistem bebas bunga, menjadi suatu perhatian yang menarik bagi seluruh kalangan ditengah sistem konvensional yang sudah dimengerti dan dipahami oleh masyarakat luas, maka karena hadirnya perbankan syariah di tengah-tengah masyarakat relatif baru, perbankan syariah dihadapi beberapa tantangan. Menurut Alamsyah (2012) tantangan yang dihadapi oleh perbankan syariah diantaranya adalah pemenuhan gap sumber daya insani yang mengerti dan memahami produk-produk keuangan syariah untuk mampu menjelaskan kepada masyarakat, inovasi pengembangan produk dan layanan perbankan syariah yang kompetitif berbasis kekhususan kebutuhan masyarakat dan kelangsungan program sosialisasi dan edukasi kepada masyarakat. Di sisi lain, karena perbankan syariah merupakan suatu perbankan dengan sistem yang baru hadir ditengah-tengah masyarakat, maka penguatan akan branding atau image dari perbankan syariah tersebut sangat diperlukan hal ini penting untuk dilakukan agar konsep-konsep yang ditawarkan oleh perbankan syariah tidak disalah artikan oleh masyarakat global (Alsheran, 2010). 


\section{METODE PENELITIAN}

Penelitian ini dilakukan dengan pendekatan deskriptif kualitatif, dengan lebih banyak bersifat uraian dari hasil wawancara mendalam dan studi dokumentasi. Data yang telah diperoleh akan dianalisis secara kualitatif serta diuraikan dalam bentuk deskriptif. Sementara sumber data yang digunakan dalam penelitian ini terdiri dari 2 sumber yaitu data primer, data yang diperoleh langsung dari responden yang menjadi subjek dalam penelitian. Data primer diperoleh dengan melakukan wawancara dan observasi langsung kepada tour guide, pengusaha perjalanan wisata dan pemilik hotel lalu data sekunder yaitu data pendukung yang diperoleh dari tempat penelitian, jurnal, buku-buku literatur dan dokumen lainnya yang ada hubungannya dengan masalah penelitian. Metode pemilihan informan untuk mendapatkan data dalam penelitian ini adalah dengan purposive sampling. Sementara, teknik analisa data dalam penelitian ini menggunakan analisis dari Miles dan Hubberman melalui pengumpulan data, reduksi data, penyajian data dan penarikan kesimpulan (Miles \& Hubberman, 2009)

\section{Reduksi Data}

\section{HASIL DAN PEMBAHASAN}

Reduksi data merujuk pada proses pemilihan, pemfokusan, penyederhanaan, abstraksi dan pentransformasian data mentah yang terjadi dalam catatan lapangan tertulis. Sebelum data dikumpulkan, reduksi data dilakukan peneliti (Setiawan, 2006) . Reduksi data berlangsung terus menerus selama penelitian kualitatif berlangsung (Putra, 2015). Sebenarnya sebelum data benar-benar terkumpul, antisipasi akan adanya reduksi data sudah tampak waktu memutuskan kerangka konseptual, wilayah penelitian, permasalahan penelitian dan pendekatan pengumpulan data yang digunakan (Miles \& Hubberman, 2009)

\section{Penyajian Data}

Setelah dilakukan reduksi hasil wawancara, selanjutnya dilakukan penyajian model data yang merupakan kumpulan informasi sebagai dasar pendeskripsian kesimpulan dan pengambilan tindakan (Putra, 2015). Menurut (Moeleong, 2007) merancang kolom dari suatu matrik untuk data kualitatif dan menentukan data yang mana, dalam bentuk yang mana, harus dimasukan kedalam sel yang mana data tersebut ditempatkan, sesuai hasil reduksi data dari berbagai literatur tentang wisata halal serta bank syariahdan hasil wawancara para informan. 
Tabel 2. Pendisplian Data

\begin{tabular}{|c|l|l|c|}
\hline \multicolumn{1}{|c|}{ No } & \multicolumn{1}{|c|}{ Tujuan Penelitian } & \multicolumn{1}{c|}{ Tema } & \multicolumn{1}{c|}{ Sumber } \\
\hline $\mathbf{1}$ & $\begin{array}{l}\text { Kondisi bank syariah } \\
\text { dalam mendukung } \\
\text { wisata halal }\end{array}$ & $\begin{array}{l}\text { Kurang sosialisasi bank syariah (seminar- } \\
\text { seminar bank syariah) }\end{array}$ & TG1, TR1, HT1 \\
\cline { 3 - 4 } & $\begin{array}{l}\text { Akses kantor cabang bank syariah dan jaringan } \\
\text { ATM yang sulit ditemui serta kecanggihan } \\
\text { teknologi yang masih belum memadai }\end{array}$ & TG1, TR1, HT1 \\
\cline { 3 - 4 } & $\begin{array}{l}\text { Kurangnya promosi dari produk-produk bank } \\
\text { syariah }\end{array}$ & TG1, TR1, HT1 \\
\hline \multirow{2}{*}{$\begin{array}{l}\text { Potensi bank syariah } \\
\text { dalam mendukung } \\
\text { wista halal }\end{array}$} & $\begin{array}{l}\text { Kekhususan produk pembiayaan bagi wisata } \\
\text { halal }\end{array}$ & TG1, TR1, HT1 \\
\cline { 3 - 4 } & $\begin{array}{l}\text { Event yang diadakan oleh bank syariah untuk } \\
\text { mendukung pariwista halal agar dapat } \\
\text { melahirkan experience bagi wisatawan }\end{array}$ & TG1, TR1, HT1 \\
\hline
\end{tabular}

Keterangan: TG = Tour Guide (1), TR = Pengusaha perjalanan wisata (2), HT = Pemilik Hotel (3)

\section{Verifikasi/Penarikan Kesimpulan}

Pemeriksaan atau verifikasi kesimpulan yang ditarik maka digunakan hasil wawncara dengan para informan agar kesimpulan yang diambil dapat dipertanggungjawabkan dan tidak diragukan keabsahannya. Berikut ini hasil penarikan kesimpulan dan verifikasi yang dilakukan dalam peran bank syariah untuk mendukung wisata halal

\section{Kurangnya Sosialisasi Yang Dilakukan oleh Bank Syariah}

Peran bank syariah dalam mendukung wisata halal masih dirasa sangat kurang. Sejauh ini para pelaku industri pariwisata menganggap bank syariah dan bank konvensional sama saja dan tidak ada bedanya, seperti yang diungkapkan oleh informan 1

"sampai saat ini, belum terasa benar perbedaan antara perbankan syariah dan perbankan konvensional, hanya katanya sistemnya yang tidak menggunakan bunga, hanya itu saja yang saya tahu yang lainnya belum terlalu paham, jadi belum berani jadi nasabah bank syariah"

Hal senada diungkapkan oleh informan 2 yang menyatakan bahwa pemahaman tentang bank syariah hanya sebatas dari sistem yang digunakan bagi hasil dan tidak menggunakan bunga namun untuk perhitungan-perhitungan yang lain masih banyak yan belum dipahami seperti yang diungkapkan berikut ini

"yang saya tahu hanya sistemnya di bank syariah menggunakan bagi hasil tidak menggunakan bunga, tetapi untuk perhitungan pengembalian biaya dan sebagainya saya masih belum paham cuman katanya kalau kita minjam ke bank syariah lebih mahal jatuhnya daripada ke bank konvensional, jadi ya ke bank konvensional aja, usaha perjalanan wisata saya pakai pembiayaan dari bank konvensional"

Begitupun dengan informan 3 yang merupakan pemilik nasabah salah satu bank syariah, pengembalian akan pinjaman tersebut dirasa jauh lebih besar daripada bank konvensional sehingga hal ini membuat pilihan utama bagi mereka untuk menjauh dari 
bank syariah dan justru cenderung beralih ke lembaga keuangan lainnya seperti lembaga pembiayaan lainnya, alasan rasional pun tetap menjadi yang utama bagi seorang nasabah dalam menentukan pilihannya membuat keputusan untuk menjadi nasabah perbankan.

\author{
"pernah suatu saat saya meminjam di bank syariah, tapi setelah dihitung \\ rasanya lebih banyak saya mengembalikan ke bank syariah daripada ke bank \\ konvensional, jadi saya gak minjem lagi di bank syariah karena jatuhnya lebih mahal \\ daripada bank konvensional sekalian aja minjem di lembaga pembiayaan lain"
}

Dari pernyataan ketiga informan tersebut sangat jelas bahwa, kondisi saat ini, bank syariah masih belum maksimal dalam melakukan sosialisasi. Sebagai suatu jenis bank yang baru muncul, bank syariah dituntut untuk mampu melakukan sosialisasi kepada seluruh lapisan masyarakat hingga masyarakat tersebut mengetahui dan memahami proses bekerjanya perbankan syariah itu sendiri (Setiawan, 2006). Menurut (Alamsyah, 2012)kegiatan untuk menggugah ketertarikan dan minat masyarakat untuk memanfaatkan produk dan layanan bank syariah harus terus dilakukan. Perbankan syariah perlu meningkatkan "kemandiriannya" dalam melakukan berbagi edukasi dan sosialisasi kepada masyarakat karena selama ini edukasi dan sosialisasi yang dilakukan sifatnya hanya menunggu dari event-event yang dilaksanakan oleh otoritas keuangan baik itu Bank Indonesia maupun Otoritas Jasa Keuangan. Di sisi lain, pemahaman dan rasional masih merupakan pilihan utama bagi masyarakat terutama bagi pengusaha, untuk menjadi nasabah bank syariah. Hal ini sesuai dengan Penelitian yang dilakukan oleh (Junaidi, 2015) yang menyatakan bahwa alasan utama masyarakat memilih menjadi nasabah bank syariah dikarenakan pemahaman masyarakat itu sendiri terhadap konsep-konsep perbankan syariah, selain itu juga penelitian yang dilakukan oleh (Wibowo \& Hadiwinoto, 2015)bahwa sikap pengusaha dalam memilih pembiayaan di bank syariah dipengaruhi oleh faktor pemahaman yang rasional dari produk-produk pembiayaan syariah itu sendiri. Ketika pembiayaan tersebut dapat menguntungkan usahanya maka pengusaha cenderung akan mengambil pembiayaan tersebut namun ketika biaya yang dikeluarkan lebih besar dan dapat mengurangi keuntungan dari usahanya maka pengusaha tersebut akan meninggalkan produk pembiayaan tersebut

\title{
Akses Kantor dan Jaringan ATM Yang Masih Sulit Ditemui
}

Dalam mendukung wisata halal, kantor dan jaringan ATM bank syariah masih sangat sulit untuk ditemui, terutama pada tempat-tempat destinasi wisata. Hal ini diungkapkan oleh informan 1 seperti berikut ini

“....baik wisatawan asing maupun wisatawan domestik jarang menggunakan bank syariah mereka menggunakan bank konvensional, soalnya sulit mengakses kantor dan jaringan ATM bank syariah apalagi di daerah-daerah wisata, jadi ya balik lagi meskipun mereka muslim, ya mau gak mau mereka menggunakan bank konvensional..."

Hal ini ditambahkan oleh informan 3, bahwa wisatawan muslim sekalipun masih sangat jarang menggunakan bank syariah karena akses kantor bank syariah beserta ATMnya sulit ditemui seperti berikut ini

6 | Optimalisasi Peran Perbankan Syariah Dalam.... 
“...wisatawan muslim yang datang ke sini jarang menggunakan bank syariah, mereka menggunakan bank konvensional juga, jadi disini yang terjangkau ya kantor sama ATM bank konvensional, itupun ditengah kota, kalau daerah-daerah wisata jarang sekali ada bank syariah..."

Wisatawan mancanegara yang didalamnya terdapat wisatawan muslim yang berlibur tidak pernah mencari dan melakukan pembayaran melalui bank syariah ini dikarenakan akses menuju kantor bank syariah masih terbatas dan layanan ATM yang sulit ditemui menyebabkan para pelaku industri wisata tidak menggunakan layanan bank syariah. Hal ini diungkapkan oleh informan 2

“...kan bank syariah itu masih terbatas jadi sulit wisatawan untuk menggunakan bank syariah, kalau bank konvensional sudah banyak jadi lebih mudah..."

Hal ini sesuai dengan hasil penelitian yang dilakukan oleh Isnandar, Firdaus, and Maulana (2016) bahwa jaringan kantor bank syariah belum merata untuk menjangkau masyarakat. Lebih jauh dari itu, jaringan kantor bank syariah dan ATM masih sangat sulit untuk ditemui di tempat-tempat wisata. Tentunya, kehadiran kantor dan jaringan ATM merupakan salah satu bentuk pelayanan yang dapat diberikan oleh bank syariah kepada masyarakat, khususnya kepada para wisatawan dan para pelaku industri wisata. Penelitian yang dilakukan oleh (Ma'arif \& Trisnawati, 2016) lokasi menjadi salah satu hal yang berpengaruh terhadap keputusan masyarakat menjadi nasabah bank syariah. Lokasi dan sarana prasarana yang mendukung akan memudahkan nasabah dalam menjalankan transaksinya. Kemudahan tersebut didapatkan apabila lokasi kantor dan jaringan ATM bank syariah berada di tempat-tempat yang strategis. Hal ini akan dapat memperkuat layanan bank syariah kepada masyarakat. Penelitian yang dilakukan oleh (Sumantri, 2014) kualitas layanan menjadi salah satu faktor yang menentukan bagi masyarakah untuk menjadi nasabah bank syariah. Sehingga, kantor dan jaringan ATM merupakan salah satu faktor kunci bagi bank syariah untuk mendapatkan nasabahnasabah baru. Hal ini sesuai dengan penelitian yang dilakukan oleh Wahyulina et al (2018) bahwa jaringan ATM yang berada di lokasi atau daerah wisata sangat penting untuk memudahkan wisatawan dalam mengambil uang tunai.

\section{Kurangnya Promosi Yang Dilakukan Bank Syariah}

Bank syariah masih sangat kurang dalam melakukan promosi. Kurangnya promosi-promosi yang menarik yang diberikan oleh bank syariah membuat wisatawan dan para pelaku industri wisata tidak menggunakan bank syariah. Hal ini diungkapkan oleh informan 3 seperti berikut ini

“...bank syariah jarang saya mendengar melakukan promosi-promosi, jadi itu juga mungkin yang menyebabkan orang belum paham tentang bank syariah..."

Hal yang sama diungkapkan oleh informan 1, dimana wisatawan sangat jarang menggunakan bank syariah karena belum paham dan mengerti tentang produk-produk perbankan syariah, di sisi lain, bank syariah masih sangat jarang mengadakan promosi 
yang dapat menarik wisatawan untuk menjadi nasabah bank syariah, seperti yang diungkapkan berikut ini

“... saya pernah bertanya kepada salah satu wisatawan mengapa tidak menggunakan bank syariah, salah satu alasannya dikarenakan jarang ada promopromo menarik, kalau bank konvensional banyak promonya seperti potongan harga kalau menggunakan debit card bank tersebut atau produk-produk yang lainnya jarang..."

Hal ini mengindikasikan bahwa bank syariah harus lebih gencar kembali untuk mengadakan promosi-promosi, baik branding dari bank syariah itu sendiri ataupun promosi melalui produk-produknya. Promosi ini penting dilakukan agar terdapat perbedaan yang jelas antara bank syariah dengan bank konvensional. Inovasi dari produk-produk perbankan syariah dalam mendukung wisata halal juga sangat dibutuhkan. Hal ini sesuai dengan penelitian yang dilakukan oleh (Yasri, 2012) bahwa alasan masyarakat menggunakan bank syariah adalah karena menjalankan hukum Islam adalah hal yang penting. Sehingga, keseluruhan siklus bisnis dan aktivitas ekonomi benar-benar berjalan berdasarkan hukum Islam. Hasil penelitian dari (Yupitri \& Sari, 2012) menemukan bahwa promosi atau mengenalkan bank syariah dan produkproduknya memiliki pengaruh yang sangat signifikan untuk dapat mempengaruhi nasabah non-muslim untuk menjadi nasabah bank syariah. Dari hasil penelitian tersebut mengindikasikan bahwa masyarakat non-muslim tertarik untuk menjadi nasabah bank syariah karena promosi yang dilakukan. Di sisi lain, Brand image bank syariah menjadi faktor penentu utama agar masyarakat tertarik untuk menggunakan bank syariah (Alsheran, 2010).

Bank syariah merupakan bank yang memiliki segmen pasar tersendiri yakni pasar religiusitas yang tinggi. Untuk itu, bank syariah dapat memanfaatkan emotional brand image. Emotional brand image merupakan cara bagi perusahaan untuk dapat menggunakan komunikasi pemasaran yang mencoba untuk mendengarkan keinginan, aspirasi dan kebutuhan dari para calon konsumen(Thompson, Rindfleisch, \& Arsel, 2006). Dengan memanfaatkan emotional brand image ini bank syariah akan lebih mudah untuk mendapatkan pangsa pasarnya dan bahkan meningkatkan market sharenya. Menurut (Thompson et al., 2006) melalui emotional brand image, konsumen akan memiliki experience terhadap suatu produk dan jasa yang dinikmatinya dan mereka akan memiliki ikatan yang sangat kuat dengan perusahaan tersebut sehingga akan menimbulkan loyalitas

\section{Kekhususan Produk Pembiayaan Bagi Pelaku Wisata Halal}

Menurut Priyanto, Fahmi, and Ismal (2016) besarnya kontribusi perbankan dalam menyalurkan pinjaman kepada sektor riil dengan menggunakan dana yang berasal dari masyarakat merupakan bentuk efektivitas perbankan dalam menjalankan fungsi intermediasinya. Bank syariah memiliki karakteristik yang berbeda dari bank konvensional pada umumnya. Bank syariah dapat menigisi segmen pasar bagi masyarakat muslim yang ingin berbisnis secara benar-benar mengikuti hukum Islam atau syariah. Islam mengatur segala aktivitas kehidupan yang dijalani oleh umatnya, termasuk untuk berbisnis (Alsheran, 2010). Maka, bank syariah dituntut untuk mengetahui dan memahami kebutuhan masyarakat tersebut termasuk kebutuhan akan

8 | Optimalisasi Peran Perbankan Syariah Dalam.... 
wisata halal. Namun, sampai dengan saat ini bank syariah belum memiliki produkproduk pembiayaan khusus bagi pelaku industri wisata seperti yang disampaikan oleh informan 3 berikut ini

"Saat ini produk pembiayaan yang ada di bank syariah masih sangat umum, sepertinya masih sama saja dengan bank konvensional sehingga membuat bank syariah belum sebagai pilihan utama saya rasa"

Ditambahkan oleh informan 2, bank syariah belum memiliki produk-produk khusus bagi pengembangan wisata halal seperti berikut ini

“...Belum ada, produk bank syariah yang saya tahu sampai sejauh ini masih umum-umum saja inginnya kita sebenarnya ada kekhususan untuk pengembangan wisata halal itu, bahkan kita ingin bank syariah itu juga ikut mengajari sebagai pengusaha perjalanan wisata untuk dapat mengimplementasikan prinsip-prinsip syariah itu sendiri gimana..."

Hal senada pun diungkapkan oleh informan 1, bank syariah sampai saat ini belum menyentuh dan memberikan produk-produk yang unik bagi para pelaku wisata halal

“... kalau saya tour guide, punya usaha travel juga kecil-kecilan tapi saya minjem di lembaga pembiayaan lain, lebih mudah saya pahami dan mengerti, kalau di bank syariah produknya sama saja, bahkan yang saya tahu cenderung lebih rumit

$$
\text { prosesnya..." }
$$

Bank syariah, sebagai lokomotif industri keuangan dalam prinsip Islam dituntut untuk mampu memberikan produk-produk khusus untuk memenuhi kebutuhan masyarakat. Menurut Alamsyah (2012) produk perbankan syariah tidak boleh hanya sekedar mengimitasi dari produk-produk yang telah ada dan telah dikeluarkan oleh bank konvensional tetapi harus memiliki suatu diferensiasi yang berbeda. Ditambahkan oleh Alamsyah (2012) bahwa inovasi pengembangan produk dan layanan perbankan syariah yang kompetitif dan berbasis kekhususan kebutuhan masyarakat akan menjadi kunci bagi keberhasilan bank syariah. Kebutuhan pada dunia wisata saat ini sangat tinggi, terlebih wisata halal yang menjadi primadona baru menuntut bank syariah sebagai suatu rangkaian keterkaitan bisnis dalam prinsip-prisnip syariah, perlu untuk membuat suatu produk-produk yang ramah bagi wisatawan ataupun bagi pelaku industri wisata. Hal ini penting untuk dilakukan, agar bisnis dan aktivitas ekonomi yang dilakukan masyarakat benar-benar halal atau dengan kata lain diperbolehkan dalam hukum-hukum Islam (Arieffiandi, Firdaus, \& Sasongko, 2016). Menurut Rusmahafi (2015) bank syariah kedepan dapat mengutamakan, atau minimal mempermudah proses pengajuan pembiayaan untuk masyarakat di bidang pariwisata syariah atau wisata halal tersebut. Kurangnya keinginan bank untuk memberikan pembiayaan kepada masyarakat di sekitar objek wisata diantaranya, disebabkan risiko yang tinggi yang ditimbulkan dari faktor alam. Risiko mengalami kerugian karena bencana alam sangat tinggi. Padahal dari sisi ekonomis, kerjasama tersebut sangat menjanjikan keuntungan yang besar bagi bank. Hal ini dikarenakan wisata halal tidak hanya bagi masyarakat muslim saja 
melainkan masyarakat non-muslim pun dapat ikut merasakan pengalaman berwisata halal (Rusmahafi, 2015).

Kompetisi di industri perbankan yang sudah ketat membuat bank syariah tidak bisa hanya mengandalkan produk-produk standar untuk menarik nasabah. Bank syariah harus mampu untuk berinovasi agar dapat menciptakan produk dan layanan yang mengedepankan uniqueness dari prinsip syariah dan kebutuhan nyata di masyarakat. Menurut Isnandar et al. (2016)bank syariah dapat mengambil kekhususan akan kebutuhan masyarakat dari setiap produk-produknya dan memberikan kekhususan pada beberapa segmen tertentu dapat menjadi salah satu strategi bank syariah untuk dapat bersaing dengan bank-bank lain yang telah lama berdiri.

\section{Event Yang diadakan bank Syariah}

Potensi yang masih sangat besar bagi tumbuhnya wisata halal ini perlu didukung oleh bank syariah. Hal ini menjadi penting karena tanpa dukungan bank syariah potensi pengembangan wisata halal tidak akan tercapai. Perlu dukungan dari seluruh pihak untuk dapat memperkenalkan bank syariah kepada masyarakat melalui event-event yang dapat mendatangkan para wisatawan, seperti yang diungkapkan oleh informan 2 berikut ini

“...Diperlukan sinergi antara pemerintah dengan bank syariah untuk dapat membuat event nasional bahkan internasional, event ini penting untuk menarik wisatawan mancanegara, jadi wisatawan tersebut mengetahui secara tidak langsung tentang bank syariah, baik tentang banknya sendiri ataupun produk-produknya, jadi lebih menarik..."

Ditambahkan oleh informan 1, bank syariah perlu membuat suatu kegiatan yang lebih fokus untuk wisatawan, seperti yang diungkapkan berikut ini

"Perlu bank syariah buat acara yang besar supaya, masyarakat lebih mengetahui keberadaan bank syariah itu dan kita jadi ingat terus dengan bank syariah"

Hal yang sama pun disampaikan oleh informan 3 yang menyatakan sebagai berikut

"Kalau bisa bank syariah buat acara yang menarik buat pelaku industri wisata ataupun wisatawan jadi ada pengalaman yang didapat dari acara yang dibuat oleh bank syariah itu"

Hal ini mengindikasikan bahwa melalui acara atau event akan menghadirkan experience bagi masyarakat. Menurut Andreani (2007)experiental marketing merujuk pada pengalaman nyata pelanggan terhadap brand/product/service untuk meningkatkan penjualan dan brand awareness. Experiental marketing juga dapat digunakan sebagai sarana untuk membangun brand equity. Brand equity mencakup interaksi gaya hidup pelanggan yang tidak dapat dipisahkan. Perusahaan perlu mengkomunikasikan asosiasi, minat, gaya hidup dari produk dan jasa yang dijual dalam konteks sosial yang luas serta dalam ikatan emosi yang kuat. Menurut (Wahyulina, Darwini, Retnowati, \& Oktaryani) hal ini dapat dilakukan melalui public relations,special events sponsorship promotions 
atau advertising. Menurut Andreani (2007) experiental marketing dapat menyangkut beberapa pendekatan seperti sense, feel, think, act dan relate. Hal ini merupakan satu kesatuan yang berusaha mengajak masyarakat untuk membedakan antara produk dari perusahaan yang satu dengan perusahaan yang lainnya. Menurut Andreani (2007) experiental marketing sangat efektif bagi perusahaan untuk membangun brand awareness, brand perception, brand equity, maupun brand loyalty hingga purchasing decision pelanggan.

Tentunya, hal ini sangat relevan apabila dilakukan oleh bank syariah dimana masyarakat masih perlu dikenalkan lebih jauh kembali tentang bank syariah ini. Di sisi lain, event yang dilakukan oleh bank syariah sangat penting untuk mencegah adanya image eksklusifitas. Menurut (Ghani, 2012) bank syariah adalah bank universal yang dapat digunakan oleh seluruh kalangan. Hasil penelitian yang dilakukan oleh (Ghani, 2012) menunjukkan bahwa bank syariah tidak lagi melakukan arabisasi secara mutlak terhadap produk-produknya karena pada kenyataannya masyarakat sebagai pasar sangat sedikit yang mengenali dan memahami istilah-istilah Arab itu sendiri.

Menurut Nengsih (2015) layanan perbankan di Indonesia harus menjangkau seluruh lapisan masyarakat Indonesia. Sistem keuangan yang semakin inklusif dapat mengalokasikan sumberdaya yang produktif semakin efisien, meningkatkan kemampuan masyarakat dalam mengelola keuangan, mengurangi pertumbuhan penyaluran kredit informal yang bersifat eksploratif (kredit oleh rentenir). Menurut Arieffiandi et al. (2016) bank syariah hadir dan dikembangkan untuk melawan cara-cara rentenir dan dilaksanakan sejalan dengan nilai moral dan prinsip sesuai syariat Islam. Peran bank syariah perlu diperluas agar masyarakat dapat ditawarkan suatu sistem perbankan yang lebih menentramkan dan bank syariah dapat berperan lebih besar bagi kesejahteraan masyarakat dengan menggerakan sektor ekonomi riil.

\section{KESIMPULAN DAN SARAN}

\section{Kesimpulan}

Hasil analisis dan pembahasan yang telah diuraikan sebelumnya maka dapat ditarik kesimpulan bahwa kondisi bank syariah dalam mendukung wisata halal belum melakukan sosialisasi yang efektif kepada para pelaku industri wisata, akses kantor dan jaringan atm yang masih sulit ditemui serta kurangnya promosi yang dilakukan oleh perbankan syariah sementara potensi bank syariah itu sendiri dapat melakukan inovasi produk dengan memberikan kekhususan produk pembiayaan bagi para pelaku industri wisata serta melakukan event yang menarik agar dapat merubah mindset masyarakat bahwa bank syariah merupakan bank yang inklusif dan bukan eksklusif

\section{Saran}

Beberapa implikasi kebijakan yang dapat dilakukan oleh bank syariah untuk mendukung wisata halal adalah dengan melakukan sosialisasi kepada pelaku wisata bahkan kepada wisatawan agar pemahaman terhadap perbankan syariah lebih komperhensif dan pada saat yang bersamaan manajemen bank syariah perlu untuk menambah akses kantor cabang maupun jaringan atm di daerah-daerah wisata agar mudah dijangkau oleh wisatawan. 
Disisi lain, bank syariah perlu untuk melakukan inovasi terhadap produk-produk yang ada pada saat ini, kekhususan produk yang dibangun oleh bank syariah akan menjadi suatu daya tarik tersendiri bagi masyarkat seperti membangun suatu produk pembiayaan khusus bagi pelaku industri wisata halal karena sebagian besar pelaku industri wisata halal berada pada sektor UMKM (Usaha Mikro Kecil dan Menengah) dan ditambah dengan melakukan berbagai event agar masyarakat mengenali dan memahami bahwa bank syariah merupakan bank yang inklusif yang dapat digunakan oleh seluruh kalangan karena sifatnya yang universal.

Untuk penelitian selanjutnya, dapat menggunakan metode lain yang lebih mendalam seperti melakukan Forum Group Discussion (FGD) baik kepada manajemen bank syariah, nasabah bank syariah, pemerintah, Bank Indonesia maupun Otoritas Jasa Keuangan agar penelitian yang dihasilkan lebih mampu mengidentifikasi hal-hal yang dapat memberikan kontribusi positif bagi optimalisasi perbankan syariah dalam mendukung wisata halal.

\section{DAFTAR PUSTAKA}

Alamsyah, H. (2012). Perkembangan dan Prospek Perbankan Syariah Indonesia: Tantangan Dalam Menyonsong MEA 2015 (pp. 1-8). Jakarta: Ikatan Ahli Ekonomi Islam (IAEI).

Alsheran, B. A. (2010). Islamic Branding: A Conceptualization of Related Terms. Journal of Brand Management, 18(1), 34-49. doi: 10.1057

Andreani. (2007). Experiental Marketing (Sebuah Pendekatan Pemasaran). Jurnal Manajemen Pemasaran, 2(1), 1-7.

Arieffiandi, R. Y., Firdaus, M., \& Sasongko, H. (2016). Faktor-Faktor Yang Mempengaruhi Tingkat Kolektibilitas Pembiayaan Sektor UMKM (Studi Kasus: Bank Syariah XYZ Kantor Cabang Jakarta Barat). Jurnal Aplikasi Bisnis dan Manajemen, 2(3), 291-303. doi: 10.17538/JABM.2.3.291

Ghani, A. (2012). Konasi Masyarakat Terhadap Penggunaan Arabic Terms dan Deskripsi Finance Scheme Dalam Pemasaran Produk Bank Syariah (Analisa Pada Masyarakat Kota Yogyakarta). Jurnal Ekonomi Syariah Indonesia, 2(2), 155-166.

Ismaeel, M., \& Blaim, K. (2012). Toward Applied Islamic Business Ethics: Responsible Halal Business. Journal of Management Development, 31(10), 1090-1100.

Isnandar, F. R., Firdaus, M., \& Maulana, A. (2016). Strategi Peningkatan Aset PT BPR Syariah Harta Insan Karimah (HIK) Ciledug. Jurnal Aplikasi Bisnis dan Manajemen, 2(1), 12-22. doi: 10.17358/JABM.2.1.12

Junaidi. (2015). Persepsi Masyarakat Untuk Memilih dan Tidak Memilih Bank Syariah. Jurnal Fokus Bisnis, 14(2), 1-13.

12 | Optimalisasi Peran Perbankan Syariah Dalam.... 
Kemenpar. (2015). Laporan Akhir Kajian Pengembangan Wisata Syariah from Kementerian Pariwisata

Ma'arif, S., \& Trisnawati, R. (2016). Faktor-Faktor Yang Mempengaruhi Keputusan Nasabah Bertransaksi di Bank Syariah. Surakarta: Universitas Muhammadiyah Surakarta.

Miles, M. B., \& Hubberman, M. (2009). Analisis Data Kualitatif: Buku Sumber Tentang Metode-Metode Baru. Jakarta: UI Press.

Moeleong, L. J. (2007). Metodologi Penelitian Kualitatif Bandung: PT Remaja Rosdakarya Offset.

Nengsih, N. (2015). Peran Perbankan Syariah Dalam Mengimplementasikan Keuangan Inklusif di Indonesia. Jurnal Etikonomi, 14(2), 221-240.

Okezone, E. (2017). Market Share Perbankan di Indonesia Hanya 5,3 Persen Di Malaysia Sudah 23,8 Persen. Keuangan Syariah. Retrieved 28 November 2017, 2017

Priyanto, T., Fahmi, I., \& Ismal, R. (2016). Faktor-Faktor Yang Mempengaruhi Pembiayaan Berbasis Bagi Hasil (Equity Financing) Pada Bank Syariah X. Jurnal Aplikasi Bisnis dan Manajemen, 2(3), 281-290. doi: 10.17358/JABM.2.3.281

Putra, I. N. N. A. (2015). Riba dan Pembiayaan Dalam Konsep Hindu. Jurnal Keuangan dan Perbanakn, 19(3), 488-496.

Rivai, H. A., Lukviarman, N., Syafrizal, Lukman, S., Adrianus, F., \& Masrizal. (2015). Identifikasi Faktor Penentu Keputusan Konsumen Dalam Memilih Jasa Perbankan: Bank Syariah VS Bank Konvensional. Jurnal CBR-Univ Andalas, 1(1), 1-17.

Rusmahafi. (2015). Upaya Penigkatan Market Share Perbankan Syariah Melalui Pariwisata Syariah dalam Menyambut Masyarakat Ekonomi ASEAN. Jakarta: UIN Jakarta.

Setiawan, A. B. (2006). Perbankan Syariah: Challenges and Opportunity Untuk Pengembangan di Indonesia. Jurnal Kordinat, 8(1), 1-15.

Sumantri, B. (2014). Pengaruh Kualitas Pelayanan dan Produk Pembiayaan Terhadap Minat dan Keputusan Menjadi Nasabah di Bank Syariah. Jurnal Economia, 10(2), 141-147.

Thompson, C. J., Rindfleisch, A., \& Arsel, Z. (2006). Emotional Branding and The Strategic Value of The Doppelganger Brand Image. Journal of Marketing, 1(1), $50-64$. 
Violita, E. S., \& Handarbeni, G. (2017). Analisis Efektivitas dan Tinjauan Audit Syariah Dalam Pelaksanaan dan Pengawasan Kepatuhan Syariah Pada Bank Syariah. Jurnal Riset Bisnis, 1(1), 41-50.

Wahyulina, S., Darwini, S., Retnowati, W., \& Oktaryani, S. (2018). Persepsi Wisatawan Muslim Terhadap Sarana Penunjang Wisata Halal di Kawasan Desa Sembalun Lawang Lombok Timur. Jurnal Magister Manajemen, 7(1), 27-39.

Wibowo, R. E., \& Hadiwinoto. (2015). Pemahaman Rasional Pembiayaan Syariah, Religiusitas, Primordialisme Pengusaha dan Pengaruhnya Terhadap Sikap Pengusaha Dalam Memilih Pembiayaan di Bank Syariah. BENEFIT Jurnal Manajemen dan Bisnis, 19(1), 45-52.

Yasri. (2012). Analisis Faktor Penentu Menjadi Nasabah Bank Syariah: Perbandingan Segmen BPR Syariah dan Bank Umum/Unit Usaha Syariah di Sumatera Barat). Jurnal Kajian Manajemen Bisnis, 1(2), 19-44

Yupitri, E., \& Sari, R. L. (2012). Analisis Faktor-Faktor Yang Mempengaruhi Non Muslim Menjadi Nasabah Bank Syariah Mandiri di Medan. Jurnal EKonomi dan Keuangan, 1(1), 46-60. 